\title{
KNOWLEDGE ABOUT EPILEPSY AMONG TEACHERS AND EPILEPTIC PATIENTS
}

\author{
MARIA F. VALLS TOSETTI * - MIRIAM A. CAMPOS * - CLAUDIA R. BAUER * \\ MÁRCIA M. ARAUJO * - SIBELLE PEDRAZOLLI * - YARA B. SILVA * \\ CRISTINA MONTOVANI * - MONICA S. HADDAD *** - A. POETCHER ** \\ A. CUKIERT**** - R. MARINO J R.*****
}

SUMMARY - 223 epileptics patients and their families and 136 teachers from public and private schools were submitted to similar questionnaires related to inheritance, transmission, cure, complilcation rates, care during seizures, need for information on the disease, habits, comparison with other diseases and to the educational and social performances of epileptics. Cure and complication nates accounted for the main differences between those populations. Epileptics could recognize a bigger number of complications but still expected to be cured from the disease. The majority of teachers and patients have never been informed about epilepsy and this finding was related to the big number of equivocal answers obtained from them. Put together, the data showed that social and educational performance of epileptic patients could be disturbed by medical and social parameters. Some, of them could be improved by an educational program towards these aspects of epilepsy.

\section{Conhecimentos acerca de epilepsia entre professores e entre pacientes epilépticos.}

RESUMO - 223 pacientes epilépticos e suas famílias e 136 professores da rede pública e privada foram submetidos a questionários similares que incluíam questões relacionadas à hereditariedade, transmissibilidade, cura, complicações, cuidados durante as crises, necessidade de informações acerca da doença, hábitos, comparações com outras doenças e performances sociais e educacionais de epilépticos. Taxas presumidas de cura e complicações representaram a maior diferença entre as duas populações. Epilépticos reconhecem um maior número de complicações mas persistem acreditando na cura de sua moléstia. A maioria dos professores e pacientes jamais havia recebido qualquer informação sobre epilepsia e isto possivelmente relaciona-se às respostas equívocas que foram obtidas. Em suma, os dados sugerem que as performances sociais e educacionais de pacientes epilépticos podem ser modificadas por parâmetros médicos e sociais, alguns dos quais podem ser melhorados através de um programa educacional direcionado aos aspectos sociais das epilepsias.

Epilepsy is one of the commonest neurologic diseases. Its $1.3 \%$ prevalence rate in São Paulo turned it to be one of our public health problems and the frequent need for continuous medical care and antiepileptic drugs availability justifies the careful planning of a social program related to this syndrome. There is a small ammount of data on the social approach to epilepsy in the medical literature $2,5,8,9$ There is almost no information from Brazilian centers 1.7. $50 \%$ of the epilepsies began before the second decade of life. Teachers are, therefore, a natural target population to study the behaviour towards epilepsy.

This is a pilot study on the knowledge about epilepsy among teachers and epileptic patients and their families, aiming to gain support for future research and social approaches.

Department of Neurology, Faculty of Medicine (FM), University of São Paulo (USP): * Nursing Student, Nursing School, USP; ** Medical Student, FMUSP; *** Medical Resident, Division of Neurology, Hospital das Clinicas (HC), FMUSP; **** Medical Resident, Division of Neurosurgery, HC, FMUSP; ***** Full Professor of Neurosurgery, FMUSP.

Dr. Arthur Cukiert - Serviço de Neurocirurgia Hospital das Clínicas FMUSP - Caixa Postal 3461 - 01060 São Paulo SP - Brasil. 


\section{METHODS}

223 consecutive adult epileptic patients and their respective families were interviewed by the nursing staff as part of their evaluation at our out-patient clinic. Questions regarding inheritance, transmittanee, cure, complication rates, care during seizures, need for information on the disease, habits, comparison of the syndrome with other diseases and the social impact of epilepsy were asked.

136 teachers from public and private schools $(56$ from private and 80 from public schools), distributed equally among primary, secondary and tertiary levels were submitted to a similar questionnaire by the same staff which also included questions regarding their behaviour towards epileptics pupils and their believes on the educational and social performance of these students. The schools to be visited were chosen aleatorily but not in a systematic equiprobabilistic fashion. analysed.

Items related to both populations were compared and individual population bias were

\section{RESULTS}

Answers related to inheritance, transmission, cure, complication rates, care during seizures and to the severity of epilepsy and other diseases could be compared in the two populations.

The majority of both patient and teachers populations do not believe in the possibility of transmission of epilepsy but still 6-32\% of them gave a positive answer. Almost 50\% of the patients believe in an inherited nature of epilepsy. This is not the case; among teachers $(\mathbf{1 9 - 2 3 \% ) .}$

Cure and complication rates were issues of disagreemnent between the two populations. $80 \%$ and $88 \%$ of the patient population believe in cure or complications of epilepsy respectively, while only $26-27 \%$ and $62-63 \%$ of the teachers did so (Table 1).

Care during the seizure among teachers consisted mainly of restrictive measures (4263\%) (Table 2). The former are also practiced by the families of epileptic patients, but at a lower frequency.

\begin{tabular}{|c|c|c|c|c|c|c|}
\hline \multirow[b]{3}{*}{ Inheritance } & \multicolumn{2}{|c|}{ Patients $(\%)$} & \multicolumn{2}{|c|}{$\begin{array}{c}\text { Public } \\
\text { Schools }(\%)\end{array}$} & \multicolumn{2}{|c|}{$\begin{array}{c}\text { Private } \\
\text { Schools }(\%)\end{array}$} \\
\hline & YES & $\mathrm{NO}$ & YES & NO & YES & NO \\
\hline & 54.3 & 45.7 & 23.7 & 67.5 & 22.5 & 77.5 \\
\hline Transmission & 32.0 & 68.0 & 7.4 & 92.5 & 10.0 & 90.0 \\
\hline Cure & 80.0 & 20.0 & 26.2 & 62.5 & 33.5 & 66.5 \\
\hline Complications & 88.0 & 12.0 & 27.5 & 72.5 & 19.6 & 81.4 \\
\hline
\end{tabular}

Table 1 - Basic knowledge about epilepsy among patients and teachers.

Patients (\%) Public Schools (\%) Private Schools (\%)

\begin{tabular}{|c|c|c|c|c|}
\hline & \multirow[b]{2}{*}{ Restrictive Measures } & \\
\hline & & 26.9 & 42.5 & 62.5 \\
\hline & Lay Down & 21.4 & 81.2 & 51.7 \\
\hline & Empirical Measures & 20.5 & 2.2 & 3.7 \\
\hline & None/Others & 26.5 & 23.7 & 28.6 \\
\hline
\end{tabular}

Table 2 - Post-ictal care provicicd by teachers and fatient's families. 


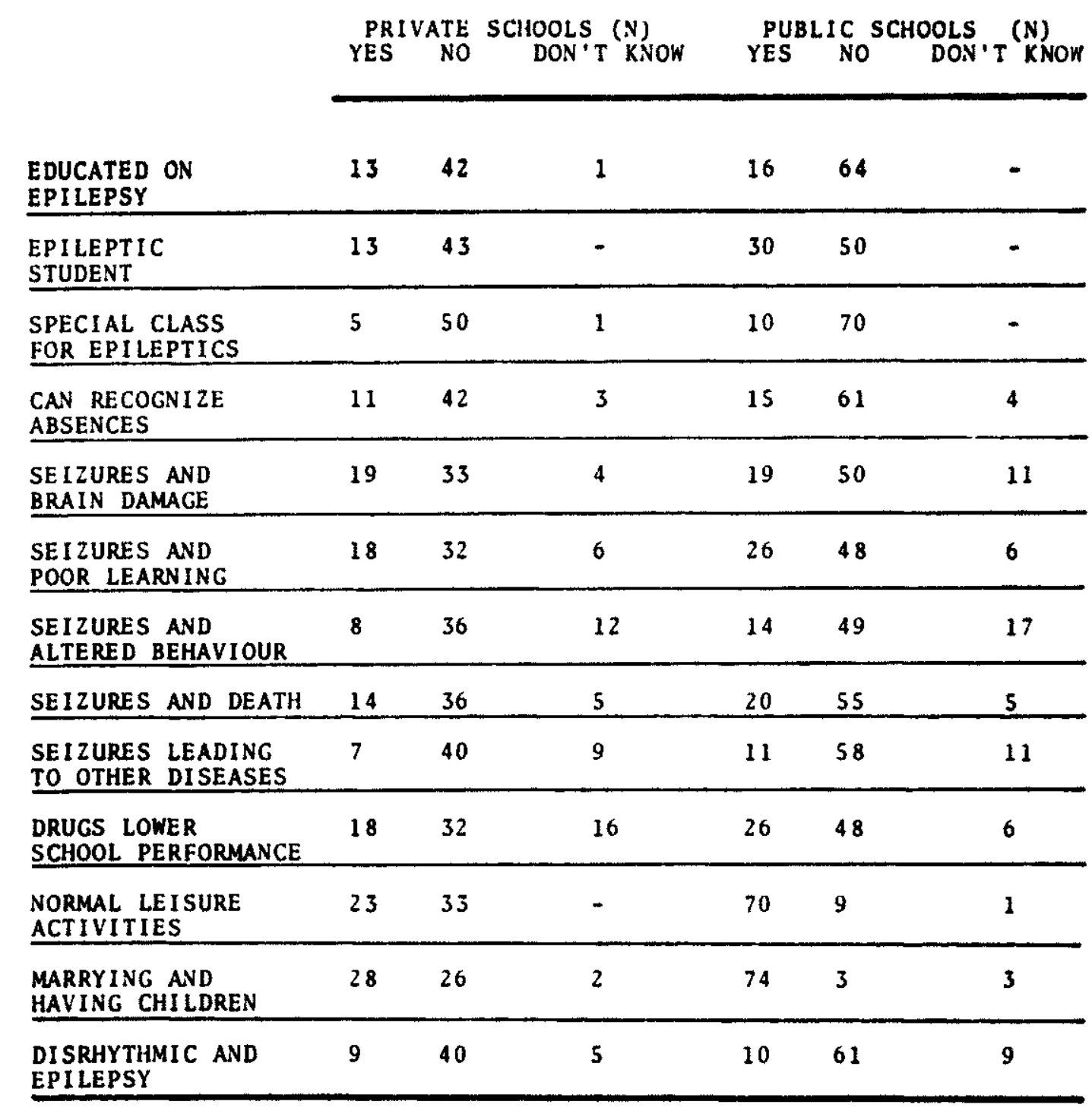

Table 3 - Data on the educational and social performances of epileptic patients.

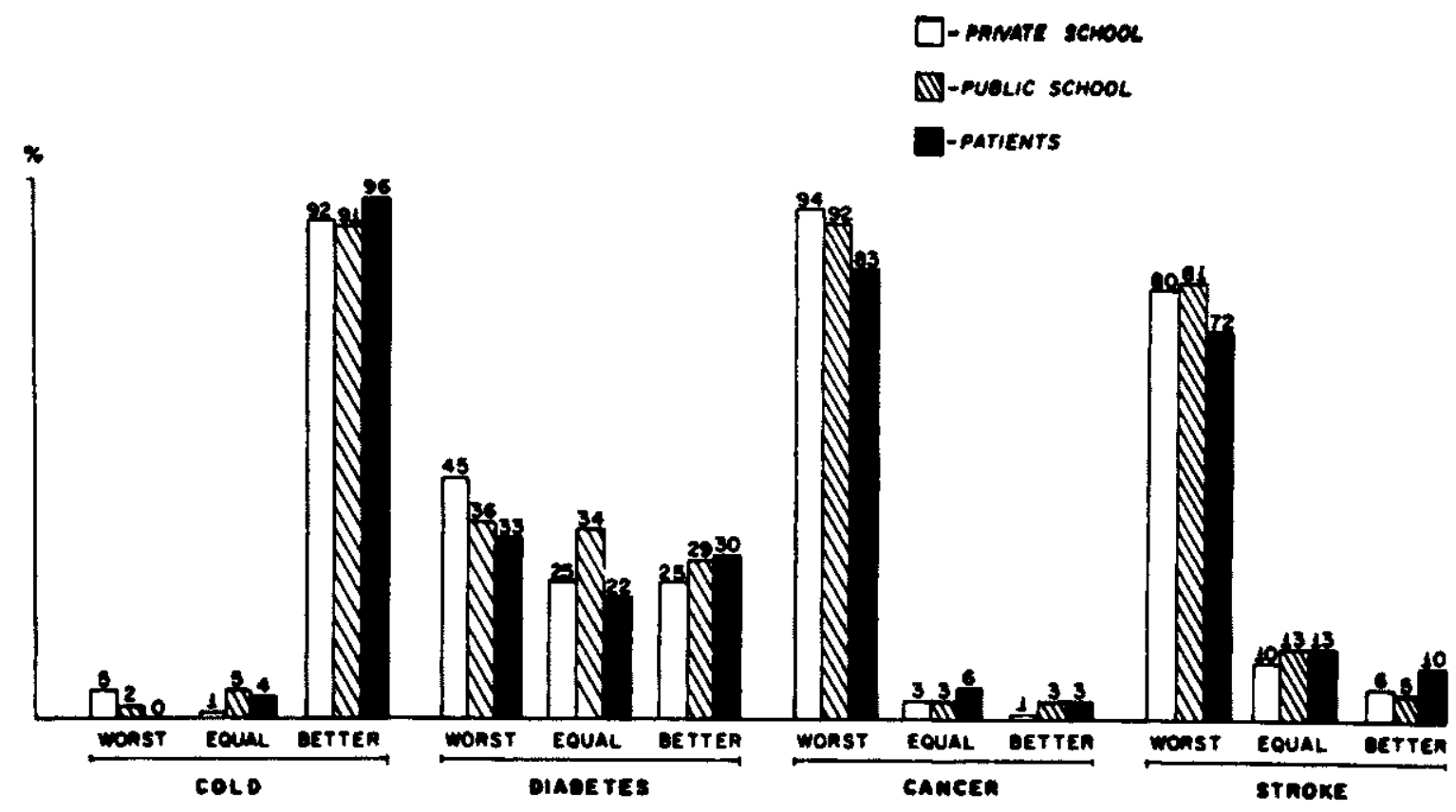

Table 4-Relative severity of epilepsy and other aiseases as viewed by epileptics and teachers. "Worst": quoted disease (cold, diabetes, cancer, stroke) is «worst» than epilepsy. The same for «equal» and abetter». 
There were no significant differences between teachers from private and public schools regarding the preceeding issues.

An overview is given in Table 3 on answers from the teachers for the questionnaire regarding their behaviour towards their epileptic students and their believes on the educational and social performances of them. More then $60 \%$ of these teachers have never been educated on epilepsy or have had any epileptic student. Most of them who answered to specific questions do not believe that there is any specific educational deficit in epileptic students but a disturbing number of them did not answered to the questions or gave a positive answer.

The only significant difference between private and public teachers appeared in social items. Private school teachers tend to be more strict to the type of activity and/or socia roles epileptics could perform than public school teachers. $58 \%$ of them do not believe epileptic students could join current leisure activities and $48 \%$ agreed that these students could not marry or have children.

Cold, diabetes, cancer and stroke were rated as better, worst or equal to epilepsy by both populations. As can be seen in table 4, the ranking from both populations was mainly acceptable from a medical point of view but still a fraction of both populations gave wrong answers.

\section{COMMENTS}

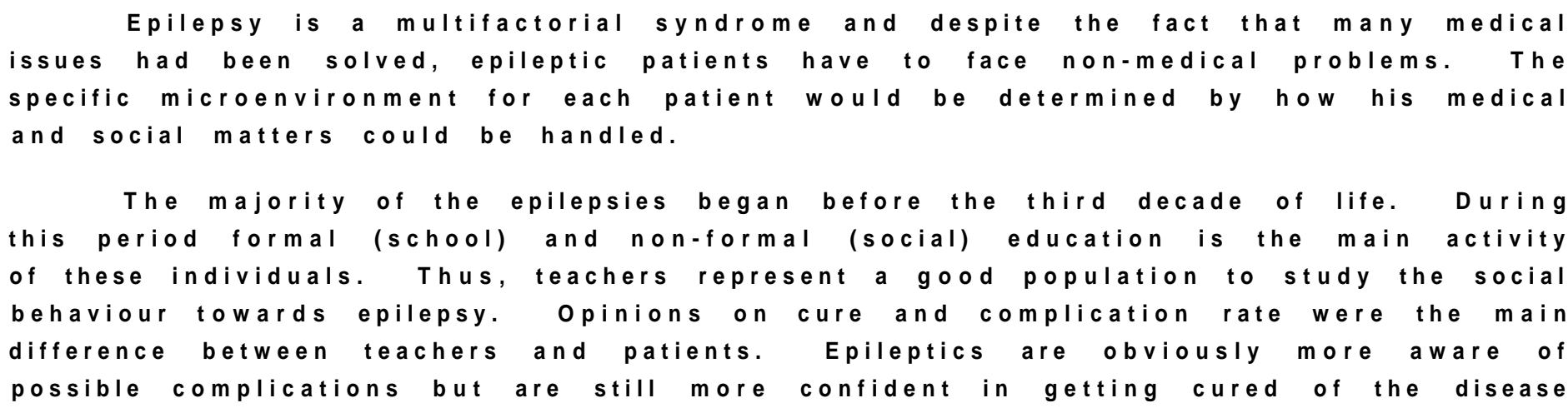

Took together, the above data suggest that despite the fact that teachers had a high-school or university degree (96\%) and a high probablity of having an epileptic student during their life, their knowledge about epilepsy, as is the case among epilep. tics themselves, is only elemental.

This pilot study indicates that a broader population based equiprobabilistic research project should be started regarding the educational and social aspects of epilepsy $\quad 3,4_{\text {s }}$

\section{REFERENCES}

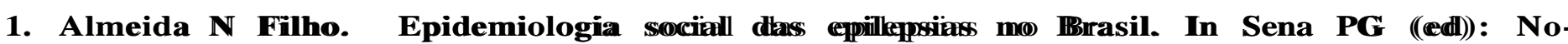
vas Achegas solbre a Epilepsia. Salkwarkorr: Centro Editorial e Didático da Universidade Federall da Balmia, 1980, p 57-78.

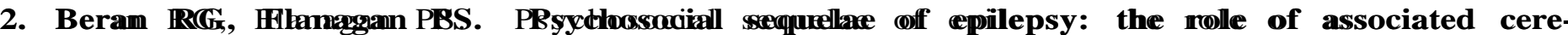
brall ppathodbogy.. Bppiteppsisia 1988,7,2828:107.

3. Corbidge P. Teacher traiiming -attituldes ttowardds eqpikepsyy. Im Oxvley J,, Stones G (edls)): Epilepsy and Education. London: Medical Tribune Group, 1987, 31-34. 
4. Craig AG, Oxley J, Dowds C. Children and Young People with Epilepsy: an Educational Package for Teachers. Chalfont St Peter: National Society for Epilepsy, 1985.

5. Dodrill CB. Correlates of generalized tonicclonic seizures with intellectual, neuropsychological, emotional and social functioning. Epilepsia 1986, 27: 399.

6. Marno R Jr, Cukiert A, Pinho E. Epidemiological aspects of epilepsy in São Paulo, Brazil: a prevalence rate study. In Wolf P, Dam M, Janz D, Dreifuss FE (eds): Advances in Epileptology, Vol 16. New York: Raven Press, 1987, p 759-764.

7. Saraiva MCS. As implicações sociais em ser epiléptico. In Marino R Jr (ed): Epilepsias. São Paulo: Sarvier, 1983, p 77-82.

8. Thompson PJ, Oxley JR. Socioeconomic accompaniments of severe epilepsy. Epilepsia 1988, 29-39.

9. Virmani V, Kaul V, Juneza J. Socioeconomic implications of epilepsy in India. In Penry JK (ed): Epilepsy 8th International Symposium. New York: Raven Press, 1977, 385-392. 